\title{
Cyclopentanoid Allylsilanes in Synthesis: A Facile Construction of the 5-8 Fused Carbon Framework of Asteriscanolide
}

\author{
Tarun K. Sarkar, * Pulak Gangopadhyay, Binay K. Ghorai, \\ Sandip K. Nandy ${ }^{+}$and Jim-Min Fang ${ }^{+}$
}

\author{
Department of Chemistry, Indian Institute of Technology, Kharagpur 721302, India \\ + Department of Chemistry, National Taiwan University, Taipei, Taiwan 106
}

Received 21 July 1998; accepted 1 September 1998

\begin{abstract}
A short synthesis of the 5-8 fused carbocyclic system of asteriscanolide, a novel cyclooctane sesquiterpene is described which entails a 5-(3,4) ene cyclization, an allylsilane induced lactone formation and a $[3,3]$ sigmatropic rearrangement in the key steps of the synthesis.

(C) 1998 Published by Elsevier Science Ltd. All rights reserved.

Key words: Cyclopentanoid allylsilanes; sigmatropic rearrangement; cyclooctane sesquiterpenes
\end{abstract}

In a series of papers, ${ }^{1,2}$ we have recently described the synthesis of cyclopentanoid allylsilanes, e.g., 2 $(R=H / M e)$ by intramolecular ene reaction ${ }^{3}$ of suitably functionalized 1,6-dienes 1 with a built-in homoallylsilane moiety as the ene donor. We have shown the versatility of the allylsilane side chain in the products by protodesilylation $2 \rightarrow 3$ and allylsilane induced ring closure $2 \rightarrow 4$ leading to differentially substituted cyclopentanes and diquinanes, respectively (Scheme 1). This new methodology has also allowed us to achieve concise syntheses of several cyclopentanoid natural products of considerable contemporary importance. ${ }^{48,9}$ Herein, we report another variation of the theme to utilize the allylsilane functionality of species such as 2 to access the cis 5-8 fused ring system 5 representing the carbocyclic core of asteriscanolide (6), a cyclooctane sesquiterpene isolated from Asteriscus aquatius $L_{\text {. }}{ }^{10}$

Scheme 1<smiles>[R][Y5]([R])(C)C/C=C/[C@H]1CC([R])([R])C[C@]1([R])CF</smiles><smiles>[R]C1([R2])C[C@@H](CC=C)[C@H](C[CH])[C@H]1CC=C</smiles><smiles>[Z]C1C[C@]2([R])CC([R])([R])C[C@H]2[C@H]1C=C</smiles><smiles>CCCCBr</smiles><smiles>CC(C)(C)O[C@H]1[C@H]2/C=C\CCC(=O)C[C@H]2C[C@]1(C)O</smiles>

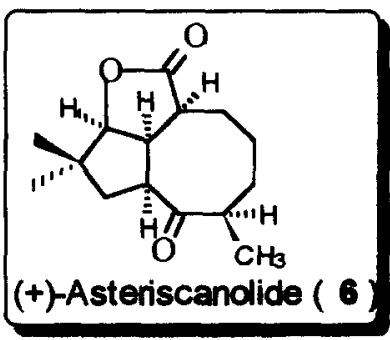

Our point of departure was the cyclopentanoid allylsilane 8, a high-yielding synthesis of which was reported earlier via thermal 5 - $(3,4)$ ene cyclization of $7^{7}$ (Scheme 2). Exposure of 8 to MCPBA followed by stirring of the crude product with silica gel (100-200 mesh) in dichloromothane gave the desired lactone 9 in $46 \%$ yield. Attempts to increase the yield in the step $8 \rightarrow 9$ by carrying out the reaction on the corresponding acid 10 was not, however, successful. Although, 9 appeared to be practically a single diastereomer ( ${ }^{1} \mathrm{H}-\&{ }^{13} \mathrm{C}-\mathrm{NMR}$ ), no attempt was made to determine the 
Scheme 2<smiles>CC(=O)/C=C\CC(C)(C)[C@H]([OH2+])/C=C/CCN(C)C</smiles>

7

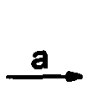



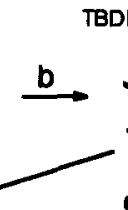

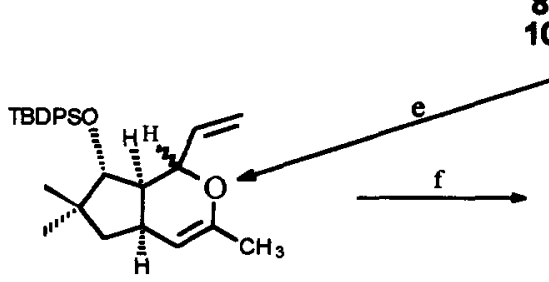

12

<smiles>CC(=O)[C@H]1CC=C[C@H]2[C@@H]1CC(C)(C)[C@@H]2O[R6](C)(F)F</smiles>

13, $\beta-\mathrm{Ha}_{a}$ $14, \alpha-\mathrm{Ha}_{\mathrm{a}}$

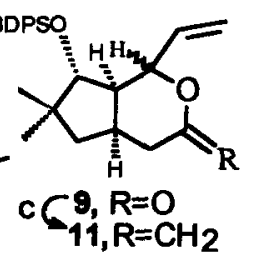

d!



a) $235^{\circ} \mathrm{C}$, tol, $18 \mathrm{~h}, 96 \%$; b) $\mathrm{MCPBA} / \mathrm{Na}_{2} \mathrm{HPO}_{4} / \mathrm{CH}_{2} \mathrm{Cl}_{2}$, r.t., then $\mathrm{SiO}_{2} / \mathrm{CH}_{2} \mathrm{Cl}_{2}$ r.t, $46 \%$; c) $\mathrm{Cp}_{2} \mathrm{TiMe}_{2} / \mathrm{THF}, 65^{\circ} \mathrm{C}, 24 \mathrm{~h}$, $65 \%$; d) $180^{\circ} \mathrm{C}$, tol, $24 \mathrm{~h}$, and then prep. HPLC, $36 \%$; e) $\mathrm{SiO}_{2} / \mathrm{CH}_{2} \mathrm{Cl}_{2} 85 \%$; f) $180^{\circ} \mathrm{C}$, tol, $24 \mathrm{~h}$.

configuration at the newly created stereogenic centre as this has no bearing on the synthesis of the target molecule. Methylenation of 9 with dimethyltitanocene under the usual conditions " afforded the extremely labile enol ether 11 (65\%). Incidentally, the slightest provocation of 11 e.g., exposure to silica gel, caused the $\pi$-bond of the enol ether unit to move into the endo position leading to the undesired product 12 . Thermolysis of $\mathbf{1 1}$ in a sealed tube coated with $\mathrm{NaOH}$, followed by chromatography, gave a mixture $(50 \%)$ of the long-sought-after ketone 5 , contaminated with the 5 6 fused ring systems 13 and $14(5: 13: 14=50: 38: 12)$. Purification of the mixture by preparative HPLC gave pure $5^{13}$ (36\%) as an oil along with 13 and somewhat impure 14 (containing $\sim 25 \%$ of 13 ). The structure and relative stereochemistry of 5,13 and 14 rest on ${ }^{1} \mathrm{H}-\&{ }^{13} \mathrm{C}$-NMR as well as nOe studies. Formation of 13 and 14 is explicable in terms of partial isomerization of 11 to 12 followed by an altemative Claisen rearrangement. In fact, when endo enol ether 12 was heated at $180^{\circ} \mathrm{C}$ for $24 \mathrm{~h}$, a mixture of 13 and $14(13 / 14=\sim 1: 1)$ was formed uncontaminated with any trace of 5 .

In conclusion, we have achieved a short synthesis of the bicyclic carbon framework of asteriscanolide via a $5-(3,4)$ ene cyclization, allylsilane induced lactonization and [3,3]sigmatropic rearrangement as the pivotal steps of the synthesis. Further transformation involving inversion of the hydroxy group after O-Si bond cleavage in 5 , five -membered lactone formation via radical reaction of the corresponding S-alkoxycarbonyl dithiocarbonate ${ }^{12}$ and other necessary elaboration would complete the synthesis of the target molecule and efforts in that direction are currently underway in this laboratory.

Acknowledgements: We are most thankful to Dr. C. Fehr and Dr. B. Maurer (Firmenich, Geneva) for detailed NMR, GC-MS and GC-FTIR work. These studies were supported by DST, New Delhi, Government of India (SP/S1/G-19/97).

References \& Notes:

1) Sarkar, T.K.; Ghosh, S.K.; Subba Rao, P.S.V.; Satapathi, T.K. Tetrahedron Lett. 1990, 31, 3461. 2) Sarkar, T.K.; Ghorai, B.K.; Nandy, S.K.; Mukherjee, B. Tetrahedron Lett. 1994, 35, 6903. 3) (a)For a review see: Mikami, K.; Shimizu, M. Chem. Rev. 1992, 92, 1021. (b)For some recent work from this laboratory see: Sarkar, T.K.; Nandy, S.K. Tetrahedron Lett. 1998, 39, 2411. 4) Sarkar, T. K.; Ghosh, S.K.; Subba Rao, P.S.V.; Mandapur, V.R. Tetrahedron Lett. 1990, 31, 3465. 5) Sarkar, T.K.; Ghosh, S.K.; Subba Rao, P. S.V.; Mandapur, V.R. Tetrahedron 1992, 48, 6897. 6) Sarkar, T.K.; Ghorai, B.K.; Bannerji, A. Tetrahedron Lett. 1994, 35, 6907. 7) Sarkar, T.K.; Ghorai, B.K.; Nandy, S.K.; Mukherjee, B.; Bannerji, A. J. Org. Chem. 1997, 62, 6006 and references cited therein. 8) Sarkar, T.K.; Mukherjee, B.; Ghosh, S.K. Tetrahedron 1998, 54, 3243. 9) For a review of allylsilanes in natural products synthesis see: Langkopf, E.; Schinzer, D. Chem. Rev. 1995, 95, 1375. 10) Isolation: Sanfeliciano, A; Barrero, A.; Medarde, M.; del Corral, J.M.M.; Aramburu, A. Tetrahedron Lett. 1985, 26, 2369. Synthesis: Wender P.A.; Thle, N.C.; Correia, C.R.D. J. Am. Chem. Soc. 1988, 110, 5904. Synthetic approaches: Booker-Milburn, K.I.; Cowell, J.K.; Harris, L.J.; Tetrahedron 1997, 53,12319 and references cited therein; Lange, G.L.; Organ, M.G. J. Org. Chem. 1996, 61, 5358. 11) Petasis, N.A; Bzowej, E.I. J. Am. Chem. Soc. 1990, 112, 6392. 12) Forbes, J.E.; Zard, S.Z. J. Am. Chem. Soc. 1990, 112, 2034. See also: Rawal, V.H.; Singh, S.P.; Dufour, C.; Michoud, C. J. Org. Chem. 1991, 56, 5245.

13) Selected spectral data for $5: v_{\max } 1703 \mathrm{Cm}^{-1}$. ' $\mathrm{H}$ NMR $\left(400 \mathrm{MHz}, \mathrm{CDCl}_{3}\right) \delta: 7.61(\mathrm{~m}, 4 \mathrm{H}), 7.32(\mathrm{~m}, 6 \mathrm{H}), 5.57(\mathrm{~m}, 1 \mathrm{H}), 4.99(\mathrm{~m}, 1 \mathrm{H})$, $3.72(\mathrm{~d}, 1 \mathrm{H}, J=3.2 \mathrm{~Hz}), 2.64(\mathrm{~m}, 1 \mathrm{H}), 2.46(\mathrm{~m}, 1 \mathrm{H}), 2.40(\mathrm{~m}, 1 \mathrm{H}), 2.28(\mathrm{~m}, 2 \mathrm{H}), 2.02(\mathrm{~m}, 1 \mathrm{H}), 1.95(\mathrm{~m}, 1 \mathrm{H}), 1.75(\mathrm{~m}, 1 \mathrm{H}), 1.50(\mathrm{~m}, 1 \mathrm{H})$, $1.07(\mathrm{~s}, 3 \mathrm{H}), 1.02(\mathrm{~s}, 9 \mathrm{H}), 1.00(\mathrm{~m}, 1 \mathrm{H}), 0.88(\mathrm{~s}, 3 \mathrm{H}) .{ }^{13} \mathrm{C} \mathrm{NMR}(75 \mathrm{MHz}) \delta: 213.93(\mathrm{~s}), 136.10(\mathrm{~d}, 4 \mathrm{C}), 134.31(\mathrm{~s}), 134.00(\mathrm{~s}), 132.76(\mathrm{~d})$, $129.51(\mathrm{~d}), 129.42(\mathrm{~d}), 129.26(\mathrm{~d}), 127.43(\mathrm{~d}, 2 \mathrm{C}), 127.36(\mathrm{~d}, 2 \mathrm{C}), 89.36(\mathrm{~d}), 48.23(\mathrm{~d}), 47.16(\mathrm{t}), 45.01(\mathrm{t}), 44.25(\mathrm{t}), 42.29(\mathrm{~s}), 37.07(\mathrm{~d})$, 28.75(q), 27.09(q, 3C), 23.49(t), 23.18(q), 19.37(s). MS m/z 389(M-Me 3 C, 30\%), 199(100\%). 